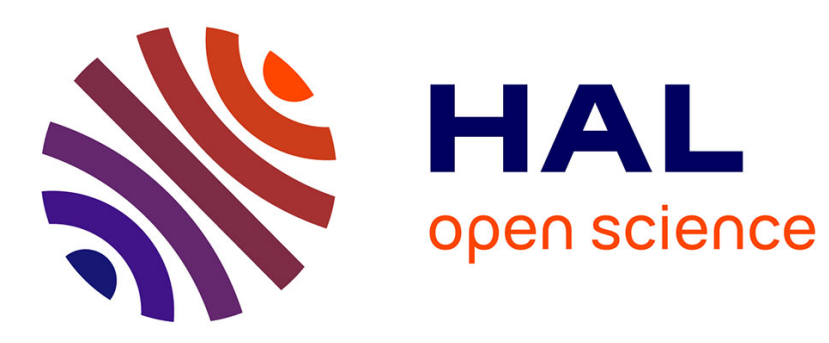

\title{
EASD review on advanced methods in structural dynamics
}

Didier Clouteau, Régis Cottereau

\section{To cite this version:}

Didier Clouteau, Régis Cottereau. EASD review on advanced methods in structural dynamics. Journal of Sound and Vibration, 2013, 332 (10), pp.2377-2378. 10.1016/j.jsv.2012.11.028 . hal-00795003

\section{HAL Id: hal-00795003 https://hal.science/hal-00795003}

Submitted on 8 Mar 2013

HAL is a multi-disciplinary open access archive for the deposit and dissemination of scientific research documents, whether they are published or not. The documents may come from teaching and research institutions in France or abroad, or from public or private research centers.
L'archive ouverte pluridisciplinaire HAL, est destinée au dépôt et à la diffusion de documents scientifiques de niveau recherche, publiés ou non, émanant des établissements d'enseignement et de recherche français ou étrangers, des laboratoires publics ou privés. 


\title{
EASD review on advanced methods in structural dynamics - Preface
}

\author{
D. Clouteau ${ }^{\mathrm{a}}$, R. Cottereau ${ }^{\mathrm{a}}$
}

${ }^{a}$ Laboratoire MSSMat UMR 8579, École Centrale Paris, CNRS, grande voie des vignes, F-92295 Châtenay-Malabry, France

\begin{abstract}
Many aspects of structural dynamics have important impacts on our lives: wind and earthquake engineering, vehicle, shuttle and train design, dam and nuclear plant analysis, vibration and noise control, and many others. The European Association of Structural Dynamics (EASD) was founded in 1990 with the goal of gathering engineers and researchers working in these areas, and, since then, it has fostered exchange of knowledge, practice and methods within this community. Such interaction has developed through the organization, every three years, of the International Conference on Structural Dynamics (EURODYN), which is devoted to theoretical development and application of structural dynamics to all types of structures and materials. Another way of disseminating knowledge among practitioners and engineers of structural dynamics has been through the sponsoring of collective publications such as the present journal special issue on advanced methods in structural dynamics.

The original impulse for the creation of this special issue was given in September 2009 by Prof. Gerhart I. Schuëller, then president of the EASD, at a meeting of the executive board of the EASD. The objective of this collective work is to present the major methods that have reached maturity during the last twenty years. It leaves aside the more traditional application-oriented works to focus on review papers with a broader range of applications. Thanks to the constant support and motivation of Prof. Schuëller, the first invitations were sent in the spring of 2011, and the last paper finally accepted in November 2012. To our deep sadness and that of the structural dynamics community, Prof. Schuëller passed away in June 2012. He could not see the completion of this work, although he made every effort to promote it. We would like to dedicate this special issue to his memory.

The first paper, by C. Soize [1], presents an overview of stochastic modeling of uncertainties. This area has seen tremendous progress in the last twenty years, and recourse to stochastic modeling has increased in both the academic and the industrial communities. The review discusses the different types of uncertainties, representations, construction and identification of the stochastic models and the propagation of uncertainties in computational models. The second and third papers, respectively by J.-S. Schotté and R. Ohayon [2] and D. Clouteau, R. Cottereau and G. Lombaert [3], discuss the modeling of structural dynamics systems coupled with heavy fluids and elastic media, respectively. The former review contemplates in particular the situation where both fluid-structure interaction and free surfaces have to be considered. The latter paper reviews issues and developments in the field of structure-environment interaction problems, in which the environment is an elastic body, possibly unbounded. It covers in particular the fields of soil-structure interaction, ground-borne noise and vibration emitted by transportation systems and wave diffraction by obstacles in an elastic medium. The paper by M. Mignolet, S. Spottswood, A. Przekop and S. Rizzi [4] deals with reduced order models (ROM), with particular relevance to geometrically nonlinear dynamical structures possibly subject to thermal effects or control forces. The form of the ROM governing equations, the estimation of their parameters, and the selection of the basis functions are reviewed in detail and comparisons are presented of predicted displacements and stresses obtained by the ROM and those obtained from full order, finite element models. The fifth paper, by E. Savin [5] addresses the theoretical modeling and numerical simulation of high-frequency dynamics of structural dynamics systems, including the influence of uncertainties. It concentrates on kinetic models that track power flows and power transfers within different parts of the structure. The approach is illustrated by several numerical examples dealing with assemblies of slender heterogeneous structures. Finally, the last paper of this issue, by B. Goller, H. J. Pradlwarter and G. I. Schuëller [6] presents a survey of methods for efficient reliability analysis of dynamical systems. The importance of the consideration of uncertainties both with respect to loading characteristics and structural parameters and questions arising from this about the reliability of a structure are thoroughly discussed.
\end{abstract}

Email addresses: didier.clouteau@ecp.fr (D. Clouteau), regis.cottereau@ecp.fr (R. Cottereau) 
We would like to thank the editors M. Cartmell, A. Metrikine and G. Degrande for endorsing the publication of this special issue. We gratefully acknowledge the contributions of the authors: it was an honor to work with them. We would also like to thank the staff of the Journal of Sound and Vibration, in particular Margaret Howls, for helping to make this issue a reality. Finally, we renew our thanks to Prof. Schuëller for injecting so much energy and belief in this special issue.

\section{References}

[1] C. Soize, Stochastic modeling of uncertainties in computational structural dynamics - recent theoretical advances, Journal of Sound and Vibration (2012). Accepted for publication.

[2] J.-S. Schotté, R. Ohayon, Linearized formulation for fluid-structure interaction. application to the vibrations of an elastic structure containing a fluid with a free surface, Journal of Sound and Vibration (2012). Accepted for publication.

[3] D. Clouteau, R. Cottereau, G. Lombaert, Dynamics of structures coupled with elastic media - a review of numerical models and methods, Journal of Sound and Vibration (2012). Accepted for publication.

[4] M. Mignolet, S. M. Spottswood, A.Przekop, S. Rizzi, Reduced models in non-linear structural dynamics, Journal of Sound and Vibration (2012). Accepted for publication.

[5] E. Savin, High-frequency dynamics of heterogeneous slender structures, Journal of Sound and Vibration (2012). Accepted for publication.

[6] B. Goller, H. J. Pradlwarter, G. I. Schüeller, Reliability assessment in structural dynamics, Journal of Sound and Vibration (2012). Accepted for publication. 